https://doi.org/10.17816/MAJ191S193-94

\title{
GASTROINTESTINAL DYSFUNCTIONS AND PERIPHERAL INFLAMMATORY CYTOKINES IN PARKINSON'S DISEASES
}

\author{
I.V. Miliukhina ${ }^{1,2,3}$, E.I. Ermolenko ${ }^{1,4}$, A.S. Ivanova ${ }^{1}$, E.V. Gracheva ${ }^{1}$, M.P. Kotyleva ${ }^{1}$, \\ E.A. Agapova ${ }^{l}$, A.N. Suvorov ${ }^{1,4}$ \\ ${ }^{1}$ Institute of Experimental Medicine, Saint Petersburg, Russia; \\ ${ }^{2}$ Pavlov's State Medical University of Saint Petersburg, Saint Petersburg, Russia; \\ ${ }^{3}$ Petersburg Nuclear Physics Institute named by B.P. Konstantinov \\ of National Research Centre "Kurchatov Institute", Saint Petersburg, Russia; \\ ${ }^{4}$ Saint Petersburg University, Saint Petersburg, Russia

\section{ГАСТРОЭНТЕРОЛОГИЧЕСКИЕ НАРУШЕНИЯ И ПЕРИФЕРИЧЕСКИЙ ВОСПАЛИТЕЛЬНЫЙ ЦИТОКИНОВЫЙ СТАТУС ПРИ БОЛЕЗНИ ПАРКИНСОНА}

\author{
И.В. Милюхина ${ }^{1,2,3}$, Е.И. Ермоленко ${ }^{1,4}$, А.С. Иванова ${ }^{1}$, Е.В. Грачева ${ }^{1}$, М.П. Котылева ${ }^{1}$, \\ E.A. Агапова ${ }^{1}$, А.Н. Суворов ${ }^{1,4}$ \\ ${ }^{1}$ ФГБНУ «Институт экспериментальной медицины», Санкт-Петербург; \\ ${ }^{2}$ ФГБОУ ВО «Первый Санкт-Петербургский государственный медицинский университет \\ им. акад. И.П. Павлова», Санкт-Петербург; \\ ${ }^{3}$ ПИЯФ им. Б.П. Константинова НИЦ «Курчатовский Институт», Санкт-Петербург; \\ ${ }^{4}$ Санкт-Петербургский государственный университет, Санкт-Петербург
}

milyukhinaiv@yandex.ru

Parkinson's disease (PD) is a neurodegenerative disease characterized by $\alpha$-synucleinopathy, which involves all districts of the brain-gut axis, including the central, autonomic and enteric nervous systems. Previous findings suggest that the intestinal microbiome is altered in PD and is related to motor phenotype. However how dysbiosis arises and whether this feature contributes to PD pathogenesis remains unknown. The aim was to evaluate gut microbiome and the serum cytokine profile in PD. We quantified serum interleukin (IL) levels (IL-1 $\beta$, IL-6, IL-10, TNF- $\alpha$, IFN- $\gamma$ ) in 55 PD patients. Study of the fecal samples was performed by real time PCR method and bacteriologically. Discovered the relationship between the intensity of dysbiosis and the level of proinflammatory cytokine IFN- $\gamma$, IL-6.

We show that disturbances in plasma cytokine level could be more profound in PD patients with altered composition of intestinal microbiota, which may explain the mechanism of influence of microbiota composition on the PD manifestations.

Keywords: Gut microbiome; gastrointestinal dysfunction; Parkinson's disease; cytokines; neuroinflammation.

Болезнь Паркинсона (БП) - нейродегенеративное заболевание, характеризующееся накоплением $\alpha$-синуклеина, которое охватывает все участки оси мозг-кишечник, включая центральную, вегетативную и энтеральную нервные системы. Последние исследования демонстрируют, что возникающие при БП изменения микробиоты кишечника влияют на моторный фенотип болезни. Однако о механизмах участия дисбактериоза в патогенезе БП известно немного. Цель исследования - оценить состав кишечной микробиоты и периферический цитокиновый профиль у пациентов с БП. Мы измерили уровни про- и противовоспалительных цитокинов в сыворотке крови (IL-1 $\beta$, IL-6, IL-10, TNF- $\alpha$, IFN- $\gamma$ ) у 55 пациентов с БП и провели оценку состава микробиоты кишечника методом ПЦР в реальном времени и бактериологически. Обнаружена связь между интенсивностью дисбактериоза и уровнем провоспалительных цитокинов IFN- $\gamma$, IL-6.

Взаимосвязь состава микробиоты и периферического цитокинового статуса вероятно является одним из механизмов влияния кишечника на патогенез БП.

Ключевые слова: микробиота кишечника; желудочно-кишечная дисфункция; болезнь Паркинсона; цитокины; нейровоспаление.

Introduction. The intestinal microbiota influence neurodevelopment, modulate behavior, and contribute to neurological disorders. However, a functional link between gut bacteria and neurodegenerative diseases remains unexplored. Parkinson's disease (PD) is the second most common neurodegenerative disorder. The dissemination of the pathological process beyond the central nervous system causes a variety of non-motor symptoms in patients with PD. Gastrointestinal dysfunction (GD), in particular constipation, affects up to $80 \%$ of PD patients. Neuroinflammation is obviously involved in PD pathogenesis. In PD microglial activation suggests a chronic inflammatory process, recent data have shown that inflammatory mediators including cytokines and chemokines could play a role in PD pathogenesis. 
Gut microbiota are different between individuals with PD and healthy controls [1, 2]. However how dysbiosis arises and whether this feature contributes to PD pathogenesis remains unknown. We sought to determine whether human gut microbiota effect on the plasma cytokine profile.

Our aim was to evaluate gut microbiome and the serum cytokine profile in PD, also assess the relationship between gut microbiome and peripheral inflammation.

Material and methods. Study was performed on the group of 55 subjects with PD in 1.5-3.0 Hoehn-Yahr (mean age 63.70 $\pm 2.3,26$ males). The investigated patients were observed in the Center for the Neurodegenerative diseases of the Institute of Experimental Medicine. The study was approved by the local ethical committee, all study participants signed an informed consent.

The diagnosis of PD was established in accordance with the MDS criteria [3]. Exclusion criteria covered a broad range of conditions and medications that could independently effect on the gut microbiota. All PD patients were using antiparkinsonian medication. L-dopa equivalent dose (LED) was calculated.

Study of the fecal samples was performed by real time polymerase chain reaction (PCR) method and bacteriologically. Cytokines (IL-1 $\beta$, IL-6, IL-10, TNF- $\alpha$ and IFN- $\gamma$ ) were measured by sandwich enzyme-linked immunosorbent assay (ELISA) (Vector-Best, Russia).
Results. In the study evaluating the frequency of various GD symptoms in 55 patients with $P D, a b-$ normal salivation, dysphagia, nausea, constipation and defecatory dysfunction were present in $60 \%$, $48 \%, 26 \%, 72 \%$, and $66 \%$ of subjects, respectively.

Among the studied parameters, only age of PD onset and LED correlated with GD dysfunction. In group patients with debut of the diseases before 45 years the level of total bacterial mass and Faecalibacterium prausnitzii was lower than in other patients $(p<0.05)$. No correlation was found between the GD symptoms and patients age, gender, antiparkinsonian treatment, level of activity or dietary fiber intake. We found the correlation between level of the IFN- $\gamma$ and Enterobacter, Escherichia coli, Lactobacillus $(r=-0.48, r=-0.45, r=-0.44)$, between level of the IL-6 and Enterobacter, Escherichia coli $(r=-0.40, r=-0.45, p<0.05)$.

Conclusion. The exact mechanisms by which gut microbiota contribute to PD are still poorly understood, despite the role of gut microbiota in the development of PD being well documented. In our study, a relationship was found between the intensity of dysbacteriosis and the level of proinflammatory cytokine IFN- $\gamma$, IL- 6 . We show that disturbances in plasma cytokine level could be more profound in PD patients with altered composition of intestinal microbiota, which may explain the mechanism of influence of microbiota composition on the PD manifestations.

\section{References}

1. Scheperjans F, Aho V, Pereira PA, et al. Gut microbiota are related to Parkinson's disease and clinical phenotype. Mov Disord. 2015;30(3):350-358.

2. Unger MM, Spiegel J, Dillmann KU, et al. Short chain fatty acids and gut microbiota differ between patients with Parkinson's disease and age-matched controls. Parkinsonism Relat Disord. 2016;(32):66-72.

3. Postuma R, Berg D, Stern M, et al. MDS clinical diagnostic criteria for Parkinson's disease. Movement Disorders. 2015;(30):1591-1601. 